\title{
Analisis Strategi Keunggulan Bersaing (Competitive Advantage) pada Balai Diklat Keuangan Makassar
}

\author{
Azwar Iskandar ${ }^{1, *}$ \\ ${ }^{1}$ Balai Diklat Keuangan Makassar, Jl. Urip Sumoharjo Km. 4, Makassar, 90234, Indonesia \\ 1 azwar.iskandar@gmail.com * \\ * corresponding author
}

\section{ARTICLE INFO}

\section{Article history}

Received 2019-11-15

Revised 2019-12-06

Accepted 2019-12-18

\begin{abstract}
This study aims to analyze strategic factors both from the internal and external environment of Makassar Financial Training and Education Center in order to develop a competitive advantage strategy. This study uses descriptive-qualitative research, with primary data consisting of data generated directly from respondents containing questions on the questionnaire sheet and secondary data obtained and available to the relevant agencies or units. Data analysis techniques used are IFAS (Summary of Internal Factory Analysis) and EFAS (Summary of External Factory Analysis) in the development of SWOT analysis. The results showed that: (1) Makassar Financial Education and Training Center in terms of development strategies have tried as optimal as possible to utilize the strengths to reduce weaknesses while the strength factor is greater than the weakness factor; (2) Makassar Financial Education and Training Center in competitive competition, placed in a relatively good position in the competition for the external environment where Makassar Financial Education and Training Center in terms of strategic development has tried its best to take advantage of existing opportunities to encourage external organization; (3) Makassar Financial Education and Training Center is currently in a strong and potential position. The strategy recommendations given are progressive in nature, where organizations in such prime and steady conditions are urgently needed to further enhance, enhance growth and obtain maximum progress; (4) The competitive advantage strategies of the Makassar Financial Education and Training Center are currently with the assistance and implementation of training programs using local wisdom in South Sulawesi in particular and Eastern Indonesia in general, for example in the tourism, culinary, and creative economy sectors and increasing The frequency of open open classes outside of regular training / training takes into account the special state financial needs of the Regional Government and there is a disruption of information technology.
\end{abstract}

\section{PENDAHULUAN}

Sebagai unit pelaksana pendidikan dan pelatihan di lingkungan Kementerian Keuangan, Balai Diklat Keuangan (BDK) Makassar sebagai unit pelaksana teknis Badan Pendidikan dan Pelatihan Keuangan (BPPK) di daerah selalu berkomitmen untuk senantiasa menjaga dan meningkatkan kualitas pembelajaran yang diselenggarakan untuk mewujudkan pelayanan prima. Komitmen menjaga kualitas pembelajaran BPPK dilakukan mulai dari tahapan perencanaan pembelajaran sampai dengan evaluasi pascapembelajaran (Iskandar dan Subekan, 2019).

Besarnya tantangan reformasi birokrasi yang disertai dengan peningkatan persaingan di era globalisasi, tuntutan masyarakat akan pelayanan prima, dan dinamisasi kehidupan bangsa yang menuntut pengelolaan keuangan negara yang kuat, serta tingginya kebutuhan aparatur keuangan negara yang handal, menuntut BDK Makassar untuk selalu siap dan berupaya menangkap peluang-peluang yang ada.

BDK Makassar diharapkan dapat menjadi garda terdepan dalam menciptakan Sumber Daya Manusia (SDM) aparatur pengelola keuangan negara yang memiliki pengetahuan, keterampilan, dan sikap mental yang baik untuk dapat melaksanakan tugas jabatan secara profesional dengan dilandasi kepribadian dan etika Aparatur Sipil Negara (ASN) sesuai dengan kebutuhan publik; mampu berperan sebagai pembaharu dan perekat persatuan dan kesatuan bangsa; dan memiliki sikap dan semangat pengabdian yang berorientasi pada pelayanan, pengayoman, dan pemberdayaan masyarakat. 
Untuk tetap eksis dan unggul dalam pelaksanaan tugas pokok dan fungsinya secara konsisten, konsukuen dan berkelanjutan, BDK Makassar wajib meningkatan akuntabilitas kinerja yang berorientasi pada pencapaian hasil dan manfaat. Semuanya akan terwujud dengan terciptanya keseimbangan kepentingan antara semua pihak (stakeholders) dalam rangka mencapai tujuan organisasi.

Untuk mencapai hal tersebut di atas, BDK Makassar perlu melakukan identifikasi faktor-faktor strategis baik dari lingkungan internal maupun eksternal untuk mengetahui dan menganalisis kekuatan, kelemahan, peluang dan ancaman yang ada dalam rangka mencapai tujuan organisasi, sasaran kinerja, dan Indikator Kinerja Utama (IKU) organisasi melalui keunggulan-keunggulan kompetitifnya. Proses identitikasi dan analisis terhadap faktor-faktor keuanggulan kompetetitif tersebut dapat dilakukan diantaranya dengan melakukan evaluasi terhadap kekuatan, kelemahan, peluang, dan ancaman yang ada melalui teknik analisis SWOT (Maisah, 2016; Rangkuti, 2015). Teknik ini merupakan suatu cara untuk mengidentifikasi berbagai faktor secara sistematis dalam rangka merumuskan strategi organisasi. Analisa ini didasarkan pada logika dalam memaksimalkan kekuatan (strength) dan peluang (opportunities) namun secara bersamaan juga meminimalkan kelemahan (weakness) dan ancaman (threats) (Rangkuti, 2015).

Analisis SWOT adalah suatu metode perencanaan strategis yang digunakan untuk mengevaluasi keempat faktor tersebut dalam suatu lembaga pendidikan (Maisah, 2016). Analisis SWOT membantu organisasi menghadapi tantangan yang berkembang sehingga dapat menjaga stabilitas dan meningkatan produktivitas (Osita, et. all, 2014). Analisis SWOT merupakan instrumen yang ampuh dalam melakukan analisis strategis, keampuhan tersebut terletak pada kemampuan para penentu strategi organisasi untuk memaksimalkan peranan faktor kekuatan dan pemanfaatan peluang sehingga sekaligus berperan sebagai alat untuk meminimalisasi kelemahan dalam tubuh organisasi, dan menekan dampak ancaman yang timbul dan harus dihadapi (Rangkuti, 2015). Alat yang dipakai untuk menyusun faktor-faktor strategis perusahaan adalah matriks SWOT. Matriks ini dapat mengambarkan secara jelas bagaimana peluang dan ancaman eksternal yang dihadapi perusahaan dapat disesuaikan dengan kekuatan dan kelemahan yang dimilikinya. Matrik ini dapat menghasilkan empat set kemungkinan alternatif strategis seperti terlihat dalam Tabel 1 berikut:

Tabel 1

Matriks Strategi Analisis SWOT

\begin{tabular}{lll}
\hline \multirow{2}{*}{ STRENGTHS $(S)$} & \multicolumn{1}{c}{ OPPORTUNITIES $(O)$} & \multicolumn{1}{c}{ THREATS $(T)$} \\
\cline { 2 - 3 } & $\begin{array}{l}\text { Strategi S-O (Kuadran I) } \\
\text { Menciptakan strategi yang } \\
\text { menggunakan kekuatan untuk } \\
\text { memanfaatkan peluang. }\end{array}$ & $\begin{array}{l}\text { Strategi S-T (Kuadran II) } \\
\text { Menciptakan strategi yang } \\
\text { menggunakan kekuatan untuk } \\
\text { mengatasi ancaman }\end{array}$ \\
\cline { 2 - 3 } WEAKNESSES $(W)$ & $\begin{array}{l}\text { Strategi W-O (Kuadran III) } \\
\text { Menciptakan strategi yang } \\
\text { meminimalkan kelemahan } \\
\text { untuk memanfaatkan peluang. }\end{array}$ & $\begin{array}{l}\text { Strategi W-T (Kuadran IV) } \\
\text { Menciptakan strategi yang } \\
\text { meminimalkan kelemahan dan } \\
\text { menghindari ancaman }\end{array}$ \\
\hline \multicolumn{3}{c}{ Sumber : Rangkuti, 2015 }
\end{tabular}

Menurut Rangkuti (2015), keberhasilan suatu strategi yang telah ditetapkan sangat ditentukan oleh seberapa besar tingkat kesesuaian strategi tersebut dengan perubahan lingkungan, pesaing, serta situasi organisasi. Untuk mengetahui daya saingnya, sebuah organisasi dapat mengunakan salah satu dari tiga strategi yaitu diferensiasi, kepemimpinan biaya, atau fokus (Porter, 2001). Karkteristik perusahaan yang bisa dikaitkan dengan setiap strategi. Sebuah keunggulan kompetitif bermakna jika hal itu berkaitan dengan aspek yang dihargai oleh pasar. Pelanggan perlu merasakan perbedaan yang konsisten dalam aspek penting antara produk produsen atau jasa dan orang-orang dari pesaingnya. Perbedaan ini harus berhubungan dengan beberapa aspek produk atau pengiriman yang termasuk kunci membeli kriteria untuk pasar. Aspek produk atau pengiriman variabel-variabel yang mempengaruhi persepsi pelanggan dari produk atau layanan, kegunaannya dan ketersediaannya. Beberapa contoh aspek tersebut adalah kualitas produk, harga dan layanan purna jual.

Dalam menciptakan keunggulan kompetitif, organisasi perlu memiliki kemampuan untuk memanfaatkan kemampuan untuk menangani masalah tertentu sebagai kemampuan tumbuh dari waktu ke waktu, untuk memanfaatkan dan menciptakan sumber daya baru, seperti keterampilan (melalui teknologi baru atau aplikasi perangkat lunak), atau untuk membuka peluang baru untuk pengembangan jenis baru 
produk. Sebuah organisasi dikatakan memiliki keuntungan kompetitif ketika perusahaan melaksanakan strategi penciptaan nilai yang pada prosesnya akan menghasilkan tenaga-tenaga profesiomal (Associate, 2012). Keunggulan kompetitif adalah sejauh mana sebuah organisasi mampu menciptakan posisi dimana dapat mempertahankan pasar selama masih adanya pesaing. Organisasi menciptakan keunggulan kompetitif melalui kemampuan kompetitif atau prioritas yang didefinisikan sebagai preferensi strategis atau dimensi dimana organisasi memilih untuk bersaing di pasar yang ditargetkan. Banyak prioritas kompetitif diidentifikasi dalam literatur (Russell dan Millar, 2014).

Beberapa penelitian terdahulu terkait analisis strategi keunggulan bersaing telah dilakukan oleh beberapa peneliti pada sektor swasta.

Sulistyawati, A. I., Indarto, I., \& Saifudin, S. (2018) meneliti beberapa faktor yang membentuk model keunggulan bersaing pada UMKM Handycraft di Kota Semarang. Hasil penelitian ini membuktikan secara empiris bahwa orientasi kewirausahaan memiliki pengaruh terbesar terhadap keunggulan bersaing. Faktor terbesar berikutnya adalah pelatihan dan orientasi pasar. Sedangkan kemampuan manajemen justru terbukti memberikan kontribusi paling rendah dalam membentuk model keunggulan bersaing pada UMKM.

Indriyani, E., Harini, C., \& Fathoni, A. (2018) melakukan penelitian untuk mengevaluasi pengembangan dan pemilihan strategi bersaing pada PT. Paragon Technology And Innovation (Wardah) dengan metode analisis SWOT (Strengths Weakness Opportunities and Threats), SAP (Strategic Advantage Profile) dan ETOP (Environmental Threat and Opportunity Profile). Hasil penelitian ini menunjukkan bahwa PT. Paragon Technology And Innovation (Wardah) dalam matrik SWOT berada dalam posisi investasi, yaitu posisi perusahaan yang mempunyai alternatif strategi atau strategi pertumbuhan.

Malik, R., \& Said, S. (2019), menguji dan menganalisis pengaruh Total Quality Management (TQM) terhadap keunggulan bersaing dan kinerja perusahaan, dan Supply Chain Management (SCM) terhadap keunggulan bersaing dan kinerja perusahaan, serta pengaruh keunggulan bersaing terhadap kinerja perusahaan pada PT Semen Tonasa Pangkep, Sulawesi Selatan, Indonesia. Hasil penelitian ini membuktikan adanya pengaruh positif dan signifikan antara Total Quality Management (TQM) terhadap Keunggulan Bersaing ,Total Quality Management (TQM) terhadap Kinerja Perusahaan, Supply Chain Management (SCM) terhadap Keunggulan Bersaing, Supply Chain Management (SCM) terhadap Kinerja Perusahaan, dan Keunggulan Bersaing terhadap Kinerja Perusahaan serta Pengaruh tidak langsung TQM dan SCM terhadap Kinerja Perusahaan melalui Keunggulan Bersaing.

Biodi, M., \& Sanawiri, B. (2017), melakukan penelitian untuk menentukan business strategy yang sesuai bagi perusahaan dalam rangka mencapai keunggulan bersaing (Studi pada Pr. Alfi Putra) dengan menggunakan pendekatan strategi generik dari Porter. Hasil penelitian menunjukkan bahwa Business Strategy (strategi bersaing) yang sesuai untuk PR. Alfi Putra adalah strategi fokus biaya. Dimana dalam strategi fokus biaya, perusahaan akan beroperasi pada wilayah sempit dengan berfokus pada kelompok pembeli tertentu dan mengabaikan kelompok pembeli yang lain. Perusahaan juga harus mencari keunggulan biaya dengan melakukan efisiensi atas produksi produk yang akan dijual kepada segmen sasarannya.

Marlina, E. (2017) melakukan penelitian untuk mengetahui apakah terdapat pengaruh penggunaan Activity Based Costing terhadap keunggulan bersaing dan kinerja perguruan tinggi di Pekanbaru. Variabel Activity Based Costing diukur dari tujuh indikator, yaitu top management Support, competition, performance evaluation and compensation, training, non-accounting ownership, resources dan consensus and clarity of objective. Variabel keunggulan bersaing diukur dengan lima indikator, yaitu harga, kualitas, delivery dependability, inovasi produk dan time to market. Hasilnya menyimpulkan bahwa Activity Based Costing berpengaruh terhadap keunggulan bersaing.

Manambing, A., Mandey, S., \& Tielung, M. V. (2018) melakukan penelitian yang bertujuan untuk mengetahui apakah orientasi pasar dan keunggulan bersaing berpengaruh terhadap kinerja pemasaran. Hasil penelitian menunjukan bahwa secara simultan orientasi pasar dan keunggulan bersaing berpengaruh positif dan signifikan terhadap kinerja pemasaran. Secara parsial orientasi pasar berpengaruh positif namun tidak signifikan terhadap kinerja pemasaran. Secara parsial keunggulan bersaing berpengaruh positif dan signifikan terhadap kinerja pemasaran. Pemilik usaha tinutuan disarankan untuk lebih meningkatkan lagi orientasi pasar agar dapat meningkatkan kinerja pemasaran UMKM di Manado.

Berdasarkan uraian di atas, BDK Makassar perlu melakukan kajian atau penelitian untuk mengidentifikasi faktor-faktor strategis baik dari lingkungan internal maupun eksternal untuk mengetahui dan menganalisis kekuatan, kelemahan, peluang dan ancaman yang ada dalam rangka mencapai keunggulankeunggulan kompetitifnya. Permasalahan yang mengemuka untuk dijawab adalah :

1. Bagaimana posisi kekuatan dan kelemahan (internal) BDK Makassar dalam hal strategi pengembangan saat ini? 
2. Bagaimana posisi peluang dan ancaman (eksternal) BDK Makassar dalam hal strategi pengembangan saat ini?

3. Bagaimana posisi BDK Makassar dalam kuadran strategi analisis SWOT?

4. Strategi keuggulan bersaing apa yang dapat diupayakan oleh BDK Makassar berdasarkan posisi dalam kuadran strategi analisis SWOT?

Untuk menjawab permasalahan tersebut, penelitian ini secara umum dilakukan dengan tujuan untuk menganalisis faktor-faktor strategis baik dari lingkungan internal maupun eksternal Balai Diklat Keuangan Makassar dalam rangka menyusun strategi keunggulan kompetitif. Adapun secara khusus, penelitian ini dilakukan dengan tujuan :

1. Untuk mengetahui posisi kekuatan dan kelemahan (internal) BDK Makassar dalam hal strategi pengembangan saat ini?

2. Untuk mengetahui posisi peluang dan ancaman (eksternal) BDK Makassar dalam hal strategi pengembangan saat ini?

3. Untuk mengetahui posisi BDK Makassar dalam kuadran strategi analisis SWOT?

4. Untuk merumuskan strategi keuggulan bersaing apa yang dapat diupayakan oleh BDK Makassar berdasarkan posisi dalam kuadran strategi analisis SWOT?

Penelitian ini berbeda dari penelitian-penelitian sebelumnya karena dilakukan pada sektor publik khusunya pada institusi pendidikan dan pelatihan. Penelitian ini diharapkan dapat membantu organisasi dalam menyusun rencana dan pilihan strategis untuk mencapai tujuan, baik itu tujuan jangka pendek maupun tujuan jangka panjang.

\section{METODE PENELITIAN}

\section{Jenis Penelitian, Data, Populasi dan Sampel}

Penelitian ini menggunakan pendekatan penelitian deskriptif-kualitatif karena dianggap mampu menggambarkan analisis lingkungan internal dan eksternal serta strategi apa yang tepat digunakan oleh Balai Diklat Keuangan Makassar dalam menghadapi persaingan global. Objek penelitian ini adalah lingkungan internal dan eksternal organisasi yang dikaji dalam variabel SWOT, yakni kekuatan, kelemahan, peluang dan ancaman. Penelitian ini menggunakan data primer dan sekunder. Data primer berupa data yang dihasilkan secara langsung dari responden berupa jawaban pertanyaan pada lembar kuesioner. Seluruh item pertanyaan dalam kuesioner tersebut menggunakan pengukuran skala Likert dengan alternatif jawaban yang disediakan yaitu : (1) Tidak Penting (TP), (2) Kurang Penting (KP), (3) Penting (P), dan (4) Sangat Penting (SP). Sedangkan data sekunder yang diperoleh dan tersedia pada instansi atau unit terkait.

Metode pengumpulan data yang digunakan adalah : (1) metode observasi dimana peneliti melakukan pengamatan langsung untuk memperoleh data atau informasi yang dibutuhkan. Fokus pengamatan tertuju pada keunggulan yang dimiliki oleh organisasi, kelemahan yang menjadi faktor penghambat organisasi, peluang yang ada saat ini dan akan datang, dan ancaman yang akan dihadapi oleh organisasi; (2) metode dokumentasi dimana peneliti melihat dan mempelajari catatan-catatan serta dokumen yang berhubungan dengan gambaran dari organisasi baik visi dan misi, keuangan, dan struktur organisasi.

Populasi dalam penelitian ini berjumlah 30 orang pegawai. Adapun sampel dalam penelitian ini diambil dengan menggunakan teknik saturation sampling (sampel jenuh). Teknik ini dipakai jika semua anggota populasi digunakan sebagai sampel, karena jumlah populasi yang relatif kecil atau penelitian ingin membuat generalisasi dengan kesalahan yang sangat kecil (Sugiyono, 2008). Berdasarkan hal tersebut, maka jumlah sampel penelitian ditetapkan sebanyak 30 orang. Jumlah ini merupakan jumlah minimal sampel yang dapat dilakukan dalam sebuah penelitian (Sekaran, 2006).

\section{Metode dan Teknik Analisis}

Penelitian ini menggunakan pendekatan Teknik Analisis SWOT. Analisis SWOT adalah suatu cara untuk mengidentifikasi berbagai faktor secara sistematis dalam rangka merumuskan strategi organisasi. Analisa ini didasarkan pada logika dalam memaksimalkan kekuatan (strength) dan peluang (opportunities) namun secara bersamaan juga meminimalkan kelemahan (weakness) dan ancaman (threats) (Rangkuti, 2015). Analisis SWOT adalah suatu metode perencanaan strategis yang digunakan untuk mengevaluasi kekuatan (strengths), kelemahan (weaknesses), peluang (opportunities), dan ancaman (threats) dalam suatu 
lembaga pendidikan (Maisah, 2016). Analisis SWOT membantu organisasi menghadapi tantangan yang berkembang sehingga dapat menjaga stabilitas dan meningkatan produktivitas (Osita, et. all, 2014).

Dengan menggunakan analisis SWOT dimungkinkan untuk membandingkan antara faktor eksternal berupa peluang (opportunities) dan ancaman (threats) dengan faktor internal berupa kekuatan (strength) dan kelemahan (weaknesses) yang menghasilkan pilihan strategi. Analisis SWOT merupakan instrumen yang ampuh dalam melakukan analisis strategis, keampuhan tersebut terletak pada kemampuan para penentu strategi organisasi untuk memaksimalkan peranan faktor kekuatan dan pemanfaatan peluang sehingga sekaligus berperan sebagai alat untuk meminimalisasi kelemahan dalam tubuh organisasi, dan menekan dampak ancaman yang timbul dan harus dihadapi (Rangkuti, 2015).

Teknik analisis data yang digunakan adalah (Rangkuti, 2014) :

1. IFAS (Internal Factory Analysis Summary), digunakan untuk menganalisis lingkungan internal perusahaan, melalui pendekatan fungsional sehingga dapat diidentifikasikan sejauh mana kekuatan dan kelemahan di daerah-daerah fungsional organisasi;

2. EFAS (External Factory Analysis Summary), digunakan untuk menganalisis berbagai hal yang menyangkut persoalan ekonomi, sosial budaya, demografi lingkungan, politik, pemerintahan, hukum, teknologi, informasi tentang persaingan di lingkungan eksternal organisasi.

Sebelum melakukan analisis terhadap data, terlebih dahulu dilakukan uji kualitas data. Pengujian kualitas data bertujuan untuk mengetahui apakah instrumen yang digunakan valid dan reliable, sebab kebenaran data yang diolah sangat menentukan kualitas hasil penelitian. Uji kualitas data yang digunakan dalam Evaluasi Pascapembelajaran ini adalah uji validitas dan realibilitas.

1. Uji validitas adalah suatu ukuran yang menunjukkan tingkat kevalidan atau kesahihan suatu instrumen (Suharsimi, 2006). Suatu kuesioner dikatakan valid jika pertanyaan pada kuesioner mampu untuk mengungkapkan sesuatu yang akan diukur oleh kuesioner tersebut. Uji signifikansi dilakukan dengan cara membandingkan nilai $r$ hitung dengan $r$ tabel untuk degree of freedom $(\mathrm{df})=\mathrm{n}-2$, dalam hal ini $\mathrm{n}$ adalah jumlah sampel.Untuk menguji apakah masing-masing indikator valid atau tidak, dapat dilihat dalam tampilan output Cronbach Alpha pada kolom Correlated Item-Total Correlation. Jika r hitung lebih besar dari $\mathrm{r}$ tabel dan nilai positif maka butir atau pertanyaan atau indikator tersebut dinyatakan valid.

2. Uji reliabilitas, menurut Ghozali (2006), adalah alat untuk mengukur suatu kuesioner yang merupakan indikator dari variabel atau konstruk. Suatu kuesioner dikatakan reliabel atau handal jika jawaban seseorang terhadap pernyataan adalah konsisten atau stabil dari waktu ke waktu. Pengukuran reliabilitas dapat dilakukan dengan dua cara yaitu : (i) repated measure atau pengukuran ulang : disini objek penelitan akan disodori soal yang sama pada waktu yang berbeda, dan kemudian dilihat apakah jawabannya sama atau tidak; (ii) one shot atau pengukuran sekali saja : di sini pengukurannya hanya sekali dan kemudian hasilnya dibandingkan dengan pertanyaan lain atau mengukur korelasi antar jawaban pertanyaan. Software SPSS menyediakan fasilitas ini dengan uji statistik Cronbach Alpha ( $\alpha$ ). Uji reliabilitas dengan menggunakan metode Cronbach Alpha $(\alpha)$ diukur berdasarkan skala Cronbach Alpha ( $\alpha$ ) 0 sampai 1. Nilai Cronbach Alpha $\geq 0.5$ dikategorikan reliable (Triton, 2005).

\section{HASIL DAN PEMBAHASAN}

\section{Profil Singkat Balai Diklat Keuangan Makassar}

Balai Diklat Keuangan (BDK) Makassar, sesuai dengan Peraturan Menteri Keuangan Nomor 177/PMK.01/2012 tanggal 6 November 2012 tentang Perubahan Atas Peraturan Menteri Keuangan Nomor 66/PK.01.2009 tentang Organisasi dan Tata Kerja Balai Pendidikan dan Pelatihan Keuangan, merupakan unit pelaksana teknis Badan Pendidikan dan Pelatihan Keuangan (BPPK) yang berada di bawah dan bertanggung jawab langsung kepada Kepala BPPK. Tugas dari Balai Diklat Keuangan Makassar adalah menyelenggaraan pendidikan, pelatihan, dan penataran keuangan negara dengan wilayah kerja meliputi Sulawesi Selatan, Sulawesi Tenggara, Sulawesi Barat, Maluku, Papua, dan Papua Barat. Dalam melaksanakan tugas dimaksud, Balai Diklat Keuangan Makassar menyelenggarakan fungsi:

1. Penyusunan program penyelenggaraan pendidikan dan pelatihan keuangan negara;

2. Pelaksanaan pendidikan dan pelatihan keuangan negara;

3. Evaluasi dan penyusunan laporan pelaksanaan pendidikan dan pelatihan keuangan negara;

4. Pemantauan pengendalian intern, pengelolaan risiko, pengelolaan kinerja, dan kepatuhan terhadap kode etik dan disiplin di lingkungan Balai Diklat;

5. Pemantauan tindak lanjut hasil pengawasan, dan pemberian rekomendasi perbaikan proses bisnis di lingkungan Balai Diklat; 
6. Pengembangan Sumber Daya Manusia (SDM) Balai Diklat;

7. Pengelolaan implementasi Teknologi Informasi dan Komunikasi; dan

8. Pelaksanaan administrasi Balai Diklat.

Balai Diklat Keuangan Makassar memiliki visi yang searah dengan visi BPPK. Adapun visi dari BPPK yakni "Menjadi lembaga pendidikan dan pelatihan terkemuka yang menghasilkan pengelola Keuangan Negara di daerah yang berkelas dunia". Visi ini kemudian menjadi inspirasi bagi Balai Diklat Keuangan Makassar dengan menetapkan visinya yaitu "Menjadi lembaga penyelenggara diklat berkelas dunia di wilayah kerjanya". Dalam menunjang dan mencapai visi baru tersebut, Balai Diklat Keuangan Makassar menetapkan misi sebagai berikut (Lakin Balai, 2019) :

1. Membangun sistem pendidikan dan pelatihan SDM Keuangan Negara yang terintegrasi dalam mewujudkan corporate university.

2. Mengelola dan mengembangkan tenaga pengajar pendidikan dan pelatihan SDM Keuangan Negara yang berkualitas.

3. Mengembangkan sarana prasarana pembelajaran yang mutakhir dan efektif dalam mendukung pembelajaran.

4. Mengembangkan teknologi informasi pendidikan dan pelatihan SDM Keuangan Negara yang berkualitas.

5. Meningkatkan kerja sama dengan institusi pendidikan dan pelatihan terbaik.

Untuk mencapai misinya, Balai Diklat Keuangan Makassar bertujuan menyelenggarakan kegiatan

Balai Diklat Keuangan yang paripurna untuk mendukung terwujudnya pengelola Keuangan Negara di daerah yang berkelas dunia. Dalam mencapai tujuan tersebut, kebijakan organisasi kemudian diarahkan pada (Lakin Balai, 2019) :

1. Terwujudnya SDM Kementerian Keuangan yang memiliki kompetensi tinggi untuk menjadi SDM yang kompetitif.

2. Tersedianya sistem pendidikan dan pelatihan yang fleksibel memenuhi kebutuhan unit pengguna.

Dalam mendukung arah kebijakannya, Balai Diklat Keuangan Makassar menetapkan dua strategi unggulan, yaitu (Lakin Balai, 2019):

1. Strategi dalam mewujudkan SDM Kementerian Keuangan yang memiliki kompetensi tinggi untuk menjadi SDM yang kompetitif yaitu dengan penyelenggaraan diklat yang berkualitas tinggi dan dengan kuantitas yang mampu memenuhi pemerataan kebutuhan diklat bagi semua pegawai;

2. Strategi dalam mewujudkan pendidikan dan pelatihan yang fleksibel memenuhi kebutuhan unit pengguna yaitu dengan peningkatan kapasitas SDM dan Sarana Prasarana Balai Diklat Keuangan Makassar yang dapat mengantisipasi kebutuhan kompetensi SDM Kementerian Keuangan di masa depan, dan peningkatan peran Balai Diklat Keuangan Makassar melalui kerja sama diklat yang dapat mendukung pengembangan SDM pengelola keuangan Negara.

Saat ini, struktur organisasi Balai Diklat Keuangan Makassar sesuai dengan Peraturan Menteri Keuangan Nomor 177/PMK.01/2012 terdiri dari :

1. Kepala Balai;

2. Kepala Subbagian Tata Usaha dan Kepatuhan Internal;

3. Kepala Seksi Penyelenggaraan;

4. Kepala Seksi Evaluasi dan Informasi;dan

5. Kelompok Jabatan Fungsional Widyaiswara.

\section{Identifikasi Lingkungan Internal dan Eksternal Balai Diklat Keuangan Makassar}

1. Lingkungan Internal Balai Diklat Keuangan Makassar, meliputi: (apakah ini sebagai sumber-sumber informan?)

a. Peserta diklat, yaitu ASN yang dipersiapkan dalam rangka memenuhi persyaratan kompetensi untuk memantapkan tugas-tugas pekerjaan teknis atau manajerial yang terkait dengan pekerjaan yang bersangkutan, sehingga mampu melaksanakan tugas dan tanggung jawabnya secara profesional. Peserta diklat di Balai Diklat Keuangan Makassar terdiri dari : ASN lingkup Kementerian Keuangan dan Kementerian/Lembaga Non- Kementerian Keuangan;

b. Widyasiwara/tenaga pengajar/fasilitator. Peraturan Kepala LAN RI No. 43 tahun 2015 menyebutkan bahwa yang dimaksud dengan tenaga pendidik di lingkup lembaga diklat pemerintah adalah widyaiswara. Widyaiswara adalah ASN yang diangkat sebagai pejabat fungsional dengan tugas, wewenang, dan hak untuk melakukan kegiatan dikjartih PNS, evaluasi dan pengembangan diklat pada Lembaga Diklat Pemerintah. Dikjartih adalah proses belajar mengajar dalam diklat baik secara 
klasikal dan/atau non klasikal. Widyaiswara dapat menyampaikan materi pembelajarannya jika telah mengikuti dan lulus sertifikasi mata diklat yang akan diampunya. Adapun Tenaga Pegajar/Fasilitator adalah pejabat/pegawai struktural yang diberi tugas oleh Kepala Balai Diklat Keuangan Makassar untuk menjadi pengajar dalam pelatihan/pembelajaran. Saat ini Balai Diklat Keuangan Makassar memiliki 2 orang orang Widyaiswara Ahli Muda. Tenaga Pengajar/Fasilitator berasala dari pejabat/pegawai struktural Balai Diklat Keuangan Makassar atau unit kerja terkait di lingkungan Kementerian Keuangan, seperti Sekretariat Jenderal, Direktorat Jenderal Pajak (DJP), Direktorat Jenderal Perbendaharaan (DJPB), Direktorat Jenderal Bea dan Cukai (DJBC), Direktorat Jenderal Kekayaan Negara (DJKN), dan lainnya;

c. Sarana dan prasarana diklat. Sarana pendidikan adalah segala sesuatu yang meliputi peralatan dan perlengkapan yang langsung digunakan dalam proses pendidikan dan pelatihan seperti gedung asrama, gedung belajar, ruangan, meja, kursi, alat peraga, LCD dan lain-lain. Sedangkan prasarana adalah semua kompenen yang secara tidak langsung menunjang jalannya proses pembelajaran di lembaga pendidikan tersebut seperti, halaman gedung, tata tertib pelatihan dan lain-lain. Sarana dan prasarana pelatihan pada Balai Diklat Keuangan Makassar saat ini meliputi gedung sekrertariat/perkantoran, gedung/ruang belajar, aula, perpustakaan, gedung asrama, ruang VIP, poliklinik, teater, lapangan voli, lapangan basket, ruang fitnes, mushallah dan lainnya;

d. Kurikulum, materi pelatihan dan proses belajar mengajar. Materi dalam kurikulum pelatihan teknis dan fungsional yang berkaitan dengan pelatihan subtantif mengacu pada kurikulum yang disusun oleh BPPK dalam hal ini pusdiklat terkait, sedangkan materi yang berkaitan diklat struktural seperti pelatihan kepemimpinan dan pelatihan dasar CPNS mengacu pada kurikulum yang telah ditetapkan oleh Pusdiklat PSDM dan Lembaga Administrasi Negara RI. Penyusunan dan pengembangan kurikulum pelatihan teknis harus berpegang kepada kompetensi jabatan, maupun kompetensi yang dibutuhkan terhadap pekerjaan teknis yang menjadi tanggung jawab PNS yang bersangkutan. Kurikulum pelatihan teknis substantif menekankan pada penguasaan pengetahuan dan atau keterampilan teknis yang berhubungan langsung dengan tugas pokok instansi baik yang berkaitan pekerjaan teknis subtantif, maupun yang berkaitan pemenuhan persyaratan diklat kepemimpinan dan diklat fungsional kurikulum diklat. Pelatihan teknis umum/administrasi dan manajemen menekankan penguasaan pengetahuan dan ketrampilan yang bersifat teknis umum/administrasi dan manajemen maupun yang berkaitan pemenuhan persyaratan pelatihan kepemimpinan dan fungsional;

e. Anggaran. Berbagai pelatihan/pembelajaran didukung oleh ketersediaan anggaran atau APBN, baik yang berasal dari DIPA Balai Diklat Keuangan Makassar maupun DIPA Pusdiklat terkait atau Kementerian/Lembaga yang menjalin kerjasama (mitra).

2. Lingkungan Eksternal Balai Diklat Keuangan Makassar, meliputi:

a. Stakeholders. Balai Diklat Keuangan Makassar perlu menjalin hubungan yang baik dan harmonis dengan seluruh stakeholders di wilayah kerjanya meliputi Sulawesi Selatan, Sulawesi Tenggara, Sulawesi Barat, Maluku, Papua, dan Papua Barat. Stakeholders di sini berasal dari unit-unit kerja Eselon I Kementerian Keuangan, Kementerian/Lembaga, dan Pemerintah Daerah (Provinsi/Kabupaten/Kota);

b. Budaya, adat istiadat, suku, bahasa, dan kearifan lokal yang ada di Sulawesi Selatan secara khusus dan Indonesia Timur secara umum. Keberadaan keragaman ini menjadi input positif bagi Balai Diklat Keuangan Makassar dalam memberikan pelayanan kepada para stakeholders-nya;

c. Aturan-aturan terkait. Peraturan yang terlalu cepat berubah mengharuskan penyelenggaraan pendidikan dan pelatihan serta pelaksanaan uji kompetensi/sertifikasi di Balai Diklat Keuangan Makassar harus responsif menyesuaikan program dan pelayanannya.

\section{Analisis SWOT Balai Diklat Keuangan Makassar}

Berikut adalah hasil observasi dan wawancara (catatan reviewer : nah apabila penelitian pendekatan ini adalah pendekatan kualitaitf maka adalah betul menggunakan teknik pengambilan data berupa wawancara, bukan suryey/quesioner) terkait dengan faktor-faktor lingkungan internal (kekuatan dan kelemahan) dan lingkungan eksternal (peluang dan ancaman) pada Balai Diklat Keuangan Makassar. 
Tabel 2

Matriks Identifikasi Faktor Lingkungan Internal dan Eksternal Balai Diklat Keuangan Makassar

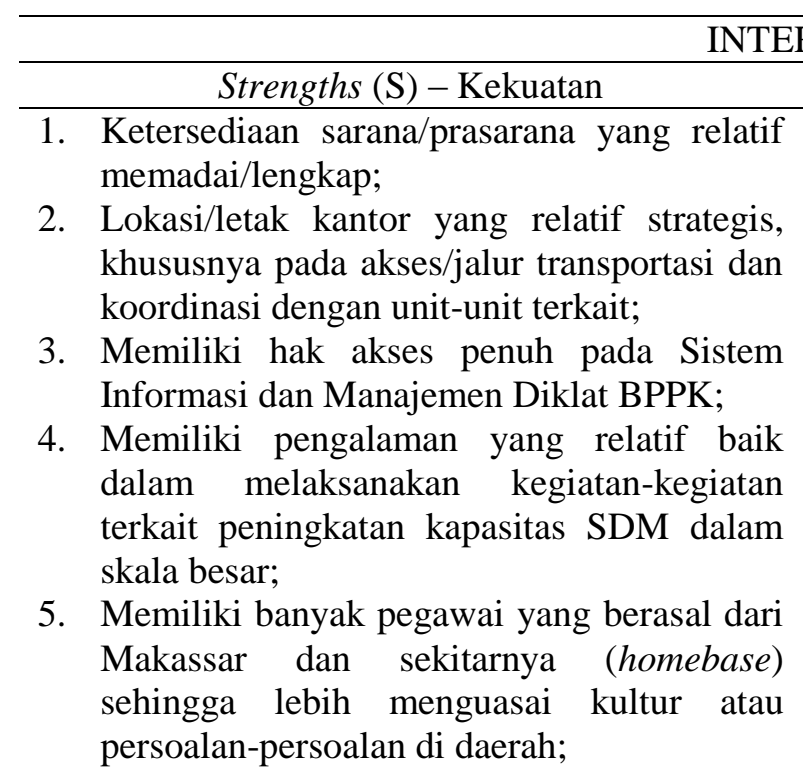

EKSTERNAL

Opportunities $(\mathrm{O})$ - Peluang

1. Wilayah/mitra kerja yang relatif luas dan besar;

2. Keragaman budaya, adat istiadat, suku, bahasa, dan kearifan lokal yang ada di Sulawesi Selatan secara khusus dan Indonesia Timur secara umum, menjadi input positif dalam pengembangan program dan pelayanan;

3. Beberapa unit kerja eselon I lain merasa bahwa kebutuhan pengembangan SDM-nya belum dapat diakomodir oleh hasil AKP di pusat;

4. Tingkat kebutuhan peningkatan kompetensi keuangan negara/daerah dari Pemerintah Daerah (Provinsi/Kabupaten/Kota) masih tinggi;

5. Dukungan penuh dari pemerintah pada peningkatan mutu SDM aparatur.
Weaknesses (W) - Kelemahan

1. Kurangnya sinergi antarunit/pegawai khususnya dalam upaya mendorong untuk bertumbuh bersama dalam pencapaian kinerja dan persaudaraan;

2. Lambatnya penangangan/respon keluhan terkait pelayanan diklat dan sarana/prasarana;

3. Jumlah tenaga widyaiswara/tenaga pengajar yang belum memadai;

4. Sulit mengakses informasi terkait potensi unit-unit kerja eselon I lainnya;

5. Tidak ada DIPA khusus atau bersama yang dapat digunakan untuk mendukung kegiatan lintas unit eselon I di daerah;

6. Distribusi beban kerja pegawai yang tidak merata;

Threats $(\mathrm{T})$ - Ancaman

1. Unit kerja eselon I lain juga mengadakan kegiatan pelatihan/workshop/in-house training;

2. Unit kerja eselon I lain memiliki akses yang lebih cepat dan update terkait perubahan aturan dan kebijakan teknis mereka;

3. Unit kerja eselon I lain juga memiliki anggaran/DIPA untuk kegiatan pengembangan SDM;

4. Kepemilikan gedung dan bangunan tidak dikelola sendiri sehingga terkesan lambat dalam merespon keluhan;

5. Terdapat pembelajaran jarak jauh yang lebih menarik dari sektor swasta;

6. Ketimpangan kompetensi pegawai antara kantor pusat dan daerah yang disebabkan tidak meratanya kesempatan mengembangkan diri karena pertimbangan efisiensi biaya;

\section{Response Rate}

\section{Sumber : data Primer (diolah)}

Jumlah responden yang ditetapkan sebagai sampel penelitian ini berjumlah 30 orang. Kuesioner penelitian telah dikirim secara online kepada seluruh responden melalui nomor Whatsapp masing-masing dengan menggunakan perangkat Google Forms. Hingga batas akhir pengembalian kuesioner, jumlah responden yang mengembalikan kuesioner dalam keadaan terisi lengkap hanya sebanyak 21 orang. Hal ini berarti tingkat pengembalian total kuesioner (response rate) hanya mencapai 80,76\% dari jumlah sampel yang ditetapkan. Meskipun response rate tidak mencapai 100\%, penelitian tetap dapat dilanjutkan ke tahapan analisis. Hartono (2011) menyebutkan bahwa response rate tidak harus mencapai 100\%, namun akan semaki 
$\mathrm{n}$ baik apabila tingkat respon semakin tinggi. Bahkan kuesioner yang dikirimkan lewat media (seperti pos atau e-mail) dengan tingkat respon sebesar 30\% sudah dapat dikatakan memadai. Terhadap kuesioner yang terisi tersebut kemudian dilakukan tabulasi, dilanjutkan dengan deskripsi dan klasifikasi responden berdasarkan jenis kelamin, pengalaman dan pendidikan serta pengolahan data.

\section{Karakteristik Responden}

Penyajian data karakteristik responden bertujuan untuk mengenal ciri-ciri khusus yang dimiliki responden sehingga memudahkan untuk melakukan analisis. Karakteristik responden berdasarkan pendidikan terakhir, pangkat/golongan, dan jabatan untuk masing-masing responden, diuraikan sebagai berikut :

Karakteristik responden berdasarkan pendidikan terakhir sebagaimana pada Tabel 3 berikut :

Tabel 3

Responden Berdasarkan Pendidikan Terakhir

\begin{tabular}{lcr}
\hline \multicolumn{1}{c}{ Karakteristik } & Jumlah (org) & Persentase (\%) \\
\hline SMA sederajat & 1 & 4,76 \\
Diploma I & 0 & 0,00 \\
Diploma III & 2 & 9,52 \\
Starata Satu (S1)/Diploma IV (DIV) & 17 & 80,95 \\
Strata Dua (S2) & 1 & 4,76 \\
Strata Tiga (S3) & 0 & 0,00 \\
\hline Jumlah & 21 & 100 \\
\hline
\end{tabular}

Sumber : data primer (diolah)

Berdasarkan Tabel 3 di atas, responden dalam kegiatan evaluasi ini berdasarkan pendidikan terakhir, untuk responden alumni sebagian besar memiliki pendidikan terakhir Starata Satu (S1)/Diploma IV (DIV) yaitu masing-masing sebanyak 17 orang atau $80,95 \%$. berikut :

Sementara itu, karakteristik responden berdasarkan pangkat/golongan sebagaimana pada Tabel 4

Tabel 4

Responden Berdasarkan Golongan/Pangkat

\begin{tabular}{lcr}
\hline \multicolumn{1}{c}{ Karakteristik } & Jumlah (org) & Persentase (\%) \\
\hline II/a (Pengatur Muda) & 0 & 0,00 \\
II/b (Pengatur Muda Tk. I) & 0 & 0,00 \\
II/c (Pengatur) & 2 & 9,52 \\
II/d (Pengatur Tk. I) & 1 & 4,76 \\
III/a (Penata Muda) & 7 & 33,33 \\
III/b (Penata Muda Tk.I) & 2 & 9,52 \\
III/c (Penata) & 5 & 23,80 \\
III/d (Penata Tk. I) & 3 & 14,28 \\
IV/a (Pembina) & 1 & 4,76 \\
\hline \multicolumn{2}{c}{ Jumlah } & 21 \\
\hline \multicolumn{2}{c}{ Sumber : data primer (diolah) }
\end{tabular}

Berdasarkan Tabel 4 di atas, responden dalam kajian ini berdasarkan pangkat/golongan, sebagian besar memiliki pangkat/golongan III/a (Penata Muda) berjumlah 7 orang atau $35 \%$.

\section{Pengujian Validitas dan Reliabilitas Instrumen}

Uji validitas dan reliabilitas instrumen dilakukan terhadap kuesioner yang sebarkan kepada alumni, rekan dan atasan. Pengujian dilakukan terhadap 10 butir pernyataan utama pada kuesioner alumni, atasan alumni dan rekan alumni. Pengujian ini dilakukan dengan bantuan program IBM SPSS Statistics 23 dengan metode Correlated Item-Total Correlation. Hasil pengujian diperoleh sebagaimana Tabel 5 berikut : 
Tabel 5

Hasil Pengujian Validitas Kuesioner

\begin{tabular}{ccc}
$\begin{array}{c}\text { Item } \\
\text { Pertanyaan }\end{array}$ & $\begin{array}{c}\text { Corrected Item- } \\
\text { Total Correlation }\end{array}$ & $\begin{array}{c}\text { r-tabel, } \\
(\mathrm{df})=21-2=19, \\
\text { alpha }=0.05 \text { (satu arah) }\end{array}$ \\
\hline $\begin{array}{c}\text { Strengths (S) - Kekuatan } \\
1\end{array}$ & .600 \\
2 & .704 \\
3 & .674 \\
4 & .846 \\
5 & .476 \\
Weaknesses (W) - Kelemahan \\
1 & .870 \\
2 & .844 \\
3 & .799 \\
4 & .567 \\
5 & .679 \\
6 & .755 \\
Opportunities (O) - Peluang \\
1 & .898 \\
2 & .466 \\
3 & .642 \\
4 & .907 \\
5 & .830 \\
Threats (T) - Ancaman & \\
1 & .698 \\
2 & .703 \\
3 & .668 \\
4 & .847 \\
5 & .532 \\
6 & .698 \\
& Sumber : data primer (diolah) \\
&
\end{tabular}

Berdasarkan Tabel 5 di atas, dengan membandingkan masing-masing nilai r-hitung (Correlation Item-Total Correlation) pada setiap item pertanyaan berdasarkan tabel di atas dengan r-tabel untuk degree of freedom $(\mathrm{df})=\mathrm{N}-2=$ dan alpha $5 \%$, di mana $\mathrm{r}$-tabel untuk kuesioner alumni=0,4124, maka dapat dinyatakan bahwa semua nilai r-hitung masing-masing pertanyaan yang digunakan sebagai instrumen untuk mengukur vaiabel penelitian baik pada kuesioner alumni, atasan alumni mamupun rekan alumni adalah lebih besar dari nilai r-tabel. Sehingga dapat dinyatakan bahwa seluruh item pertanyaan pada instrumen penelitian (kuesioner) adalah valid.

Selanjutnya, pengujian realibilitas dengan metode Cronbach Alpha juga dilakukan terhadap 22 butir pernyataan pada kuesioner. Pengujian realibiltas atas instrumen penelitian (kuesioner) ini dilakukan dengan bantuan program IBM SPSS Statistics 23 diperoleh hasil sebagai berikut :

Tabel 6

Hasil Uji Reliabilitas Kuesioner

\begin{tabular}{ccc}
\hline \multirow{2}{*}{ Kuesioner } & \multicolumn{2}{c}{ Reliability Statistics } \\
& Cronbach's Alpha & N of Items \\
\hline Responden & 0.92 & 21 \\
\hline & Sumber : data primer (diolah)
\end{tabular}

Berdasarkan Tabel 6 di atas, dengan membandingkan nilai Cronbach Alpha instrumen penelitian dengan nilai kriteria realibilitas sebagaimana yang disebutkan oleh Triton (2005), maka dapat dinyatakan 
bahwa instrumen penelitian adalah sangat reliable yaitu berada nilai Cronbach Alpha yang melebihi nilai ambang batas. Hal ini berarti semua butir pernyataan mempunyai kehandalan/konsistensi yang dapat dipertanggungjawabkan (reliabel).

\section{Analisis IFAS (Internal Factory Analysis Summary)}

Hasil analisis faktor lingkungan internal dapat dilihat pada Tabel 5. Berdasarkan Matriks IFAS pada tabel tersebut terlihat bahwa posisi Balai Diklat Keuangan Makassar dalam keunggulan kompetitif, berada pada posisi relatif baik dalam menghadapi lingkungan internalnya dengan total nilai 2,58. Hal ini berarti bahwa Balai Diklat Keuangan Makassar dalam hal strategi pengembangan telah mencoba seoptimal mungkin untuk memanfaatkan kekuatan untuk mengurangi kelemahan. Pada Tabel 5 juga dapat dilihat bahwa total skor variabel kekuatan lebih besar daripada total skor variabel kelemahan $(\mathrm{x}>0)$, dengan selisih total skor kekuatan-kelemahan sebesar 2,13. Hal ini menunjukkan bahwa faktor kekuatan lebih dominan daripada kelemahan.

Tabel 7

Matriks IFAS Balai Diklat Keuangan Makassar

\begin{tabular}{|c|c|c|c|c|}
\hline Pertanyaan & Jumlah & Rating & Bobot & $\begin{array}{c}\text { Skor (Bobot x } \\
\text { Rating) }\end{array}$ \\
\hline \multicolumn{5}{|l|}{ Strengths (S) - Kekuatan } \\
\hline 1 & 74 & 3,70 & 0,14 & 0,50 \\
\hline 2 & 78 & 3,90 & 0,14 & 0,56 \\
\hline 3 & 76 & 3,80 & 0,14 & 0,53 \\
\hline 4 & 72 & 3,60 & 0,13 & 0,47 \\
\hline 5 & 73 & 3,65 & 0,13 & 0,49 \\
\hline \multicolumn{3}{|c|}{ Jumlah Bobot dan Skor S } & 0,68 & 2,54 \\
\hline \multicolumn{5}{|l|}{ Weaknesses (W) - Kelemahan } \\
\hline 1 & 28 & 1,40 & 0,05 & 0,07 \\
\hline 2 & 30 & 1,50 & 0,05 & 0,08 \\
\hline 3 & 27 & 1,35 & 0,05 & 0,07 \\
\hline 4 & 27 & 1,35 & 0,05 & 0,07 \\
\hline 5 & 35 & 1,75 & 0,06 & 0,11 \\
\hline 6 & 28 & 1,40 & 0,05 & 0,07 \\
\hline \multicolumn{3}{|c|}{ Jumlah Bobot dan Skor W } & $\mathbf{0 , 3 2}$ & $\mathbf{0 , 4 7}$ \\
\hline Jumlah Bobot dan Skor S+W & & 548 & 1,00 & 3,02 \\
\hline \multicolumn{4}{|c|}{ Selisih Skor S dan W (S-W) } & 2,07 \\
\hline
\end{tabular}

Sumber : data primer (diolah)

\section{Analisis EFAS (External Factory Analysis Summary)}

Hasil analisis faktor lingkungan eksternal dapat dilihat pada Tabel 6. Berdasarkan Matriks EFAS pada tabel tersebut terlihat bahwa posisi Balai Diklat Keuangan Makassar dalam keunggulan kompetitif, berada pada posisi relatif baik dalam menghadapi lingkungan eksternalnya dengan total nilai 2,59. Hal ini berarti bahwa Balai Diklat Keuangan Makassar dalam hal strategi pengembangan telah mencoba seoptimal mungkin untuk memanfaatkan peluang yang ada untuk menghadapi ancaman. Pada Tabel 6 juga dapat dilihat bahwa total skor variabel peluang lebih besar daripada total skor variabel ancaman $(\mathrm{y}>0)$, dengan selisih total skor kekuatan-kelemahan sebesar 2,17. Hal in menunjukkan bahwa faktor peluang lebih dominan daripada ancaman. 
Tabel 8

Matriks EFAS Balai Diklat Keuangan Makassar

\begin{tabular}{|c|c|c|c|c|}
\hline Pertanyaan & Jumlah & Rating & Bobot & $\begin{array}{c}\text { Bobot } \mathrm{x} \\
\text { Rating }\end{array}$ \\
\hline \multicolumn{5}{|l|}{ Opportunities (O) - Peluang } \\
\hline 1 & 73 & 3,65 & 0,13 & 0,49 \\
\hline 2 & 73 & 3,65 & 0,13 & 0,49 \\
\hline 3 & 76 & 3,80 & 0,14 & 0,53 \\
\hline 4 & 75 & 3,75 & 0,14 & 0,51 \\
\hline 5 & 75 & 3,75 & 0,14 & 0,51 \\
\hline \multicolumn{3}{|c|}{ Jumlah Bobot dan Skor O } & 0,68 & 2,53 \\
\hline \multicolumn{5}{|l|}{ Threats $(\mathrm{T})$ - Ancaman } \\
\hline 1 & 33 & 1,65 & 0,06 & 0,10 \\
\hline 2 & 25 & 1,25 & 0,05 & 0,06 \\
\hline 3 & 31 & 1,55 & 0,06 & 0,09 \\
\hline 4 & 25 & 1,25 & 0,05 & 0,06 \\
\hline 5 & 30 & 1,50 & 0,05 & 0,08 \\
\hline 6 & 31 & 1,55 & 0,06 & 0,09 \\
\hline \multicolumn{3}{|c|}{ Jumlah Bobot dan Skor T } & $\mathbf{0 , 3 2}$ & $\mathbf{0 , 4 7}$ \\
\hline Jumlah Bobot dan Skor O + T & 547 & & 1,00 & 3,00 \\
\hline \multicolumn{4}{|c|}{ Selisih Skor O dan T (O-T) } & 2,07 \\
\hline
\end{tabular}

Berdasarkan matriks evaluasi faktor internal dan eksternal di atas dapat dibuat titik koordinat posisi pada Kuadran Model SWOT untuk melihat dimana posisi strategi keunggulan bersaing Balai Diklat Keuangan Makassar. Setelah diperoleh nilai tertimbang dalam matriks evaluasi faktor internal dan eksternal, diperoleh data sebagai berikut:

1. Selisih antara kekuatan dan kelemahan (sebagai sumbu $\mathrm{X}$ dalam kuadran strategi) :

$\mathrm{S}-\mathrm{W}=2,54-0,47=2,07$

2. Selisih antara peluang dan tantangan (sebagai sumbu Y dalam kuadran strategi) :

$\mathrm{O}-\mathrm{T}=2,53-0,47=2,07$

Grafiknya dapat digambar sebagai berikut:

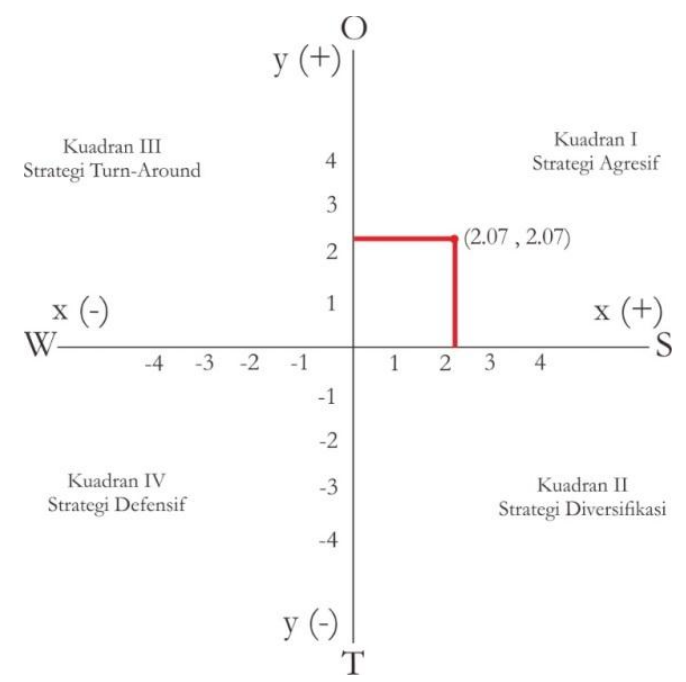

Grafik 1. Koordinat Posisi Strategi Keunggulan Bersaing

Balai Diklat Keuangan Makassar 
Pada Grafik 1 dapat terlihat bahwa titik koordinat berada pada kuadran I (positif, positif). Hal ini menandakan menandakan bahwa Balai Diklat Keuangan Makassar saat ini berada pada posisi yang kuat dan berpeluang. Rekomendasi strategi yang diberikan adalah progresif, artinya organisasi dalam kondisi prima dan mantap sehingga sangat dimungkinkan untuk lebih melakukan ekspansi, memperbesar pertumbuhan dan meraih kemajuan secara maksimal.

Strategi-strategi keunggulan bersaing Balai Diklat Keuangan Makassar dapat dilakukan dengan beberapa alternatif. Penentuan alternatif strategi yang dapat dikembangkan dapat dilihat pada Tabel 8 berikut :

\section{Tabel 9}

Matriks Alternatif Strategi Keunggulan Bersaing Hasil Analisi SWOT Balai Diklat Keuangan Makassar

\begin{tabular}{|c|c|c|}
\hline & OPPORTUNITIES (O) & THREATS (T) \\
\hline STRENGTHS (S) & $\begin{array}{l}\text { Strategi S-O (Kuadran I) } \\
\text { 1. Merancang dan melaksanakan } \\
\text { program pelatihan dengan } \\
\text { memanfaatkan kearifan lokal } \\
\text { yang ada di Sulawesi Selatan } \\
\text { secara khusus dan Indonesia } \\
\text { Timur secara umum, misalnya } \\
\text { pada sektor wisata, kuliner, dan } \\
\text { ekonomi kreatif (S1,S3,S4,S5, } \\
\text { O2,O6) } \\
\text { 2. Memperbanyak frekuensi } \\
\text { pelaksanaan Open Class di luar } \\
\text { pelatihan/pembelajaran regular } \\
\text { mengingat : (i) tingginya } \\
\text { kebutuhan kompetensi keuangan } \\
\text { negara khususnya dari } \\
\text { Pemerintah Daerah; dan (ii) } \\
\text { disrupsi teknologi informasi } \\
\text { (S1,S2,S4,S5,O3,O4,O5); }\end{array}$ & $\begin{array}{l}\text { Strategi S-T (Kuadran II) } \\
\text { 1. Menjalin komunikasi yang } \\
\text { intens kepada seluruh unit } \\
\text { eselon I lainnya akan fungsi } \\
\text { dan tugas pokok BPPK dalam } \\
\text { pengembangan SDM di } \\
\text { lingkungan Kementerian } \\
\text { Keuangan (S1,S2,T1,T2); } \\
\text { 2. Mengajukan permohonan } \\
\text { pengalihan hak milik dan } \\
\text { pengelolaan gedung/bangunan } \\
\text { ke pihak terkait (S1,S2,T3); } \\
\text { 3. Mengusulkan ke pusat untuk } \\
\text { memperbanyak pelatihan } \\
\text { dengan metode/model e- } \\
\text { larning atau blended learning } \\
\text { (S1,S5,T2,T5). }\end{array}$ \\
\hline WEAKNESSES (W) & $\begin{array}{l}\text { Strategi W-O (Kuadran III) } \\
\text { 1. Meningkatkan sinergi, } \\
\text { komunikasi, koordinasi dan } \\
\text { kebersamaan antarunit/pegawai } \\
\text { di lingkungan kantor } \\
\text { (W1,O1,O2,O3,O4,O5); } \\
\text { 2. Mengajukan permohonan } \\
\text { penambahan tenaga widyaiswara } \\
\text { ke kantor pusat (W3,O5) }\end{array}$ & $\begin{array}{l}\text { Strategi W-T (Kuadran IV) } \\
\text { 1. Meningkatkan jumlah } \\
\text { widyaiswara teknis sehingga } \\
\text { unit eselon I lainnya tidak lagi } \\
\text { melaksanakan in-house } \\
\text { training sendiri karena } \\
\text { widyaiswara/narasumber } \\
\text { teknis sudah tersedia di Balai } \\
\text { (W3, T1); } \\
\text { 2. Menjalin kerjasama (MoU) } \\
\text { dengan unit eselon I lainnya } \\
\text { terkait terkait perubahan aturan } \\
\text { dan kebijakan teknis sebagai } \\
\text { input untuk pelaksanaan } \\
\text { program pelatihan (W4, T1, } \\
\text { T2). }\end{array}$ \\
\hline
\end{tabular}




\section{Pembahasan}

Strategi yang akan diambil disesuaikan dengan posisi keberadaan kuadran. Strategi yang dapat dilaksanakan berdasarkan kombinasi faktor internal dan eksternal organisasi yaitu dengan Strategi SO (strengths-opportunities). Strategi ini dibuat berdasarkan fakta yang ada pada Balai Diklat Keuangan Makassar yang berada dalam kuadran I. Keberadaan yang dominan di kuadran I ini berarti strategi yang diprioritaskan adalah agresif. Balai Diklat Keuangan Makassar perlu menggunakan seluruh kekuatan yang dimilikinya sehingga dapat memanfaatkan peluang yang ada. Strategi agresif ini dapat ditempuh melalui berbagai program sebagai berikut :

Pertama, Balai Diklat Keuangan Makassar perlu merancang dan melaksanakan program pelatihan dengan memanfaatkan kearifan lokal yang ada di Sulawesi Selatan secara khusus dan Indonesia Timur secara umum, misalnya pada sektor wisata, kuliner, dan ekonomi kreatif. Diantara bentuk pelatihan tersebut adalah Pelatihan Persiapan Purnabakti. Pelatihan ini dimaksudkan untuk membekali para pegawai di lingkungan Kementerian Keuangan dengan persiapan-persiapan yang diperlukan dalam memasuki masa purnabakti agar memiliki kesiapan mental dan kesehatan serta tetap mampu berkarya di masa purnabakti. Di antara Standar Kompetensi yang diharapkan dalam pelatihan ini adalah cara pengembangan usaha di bidang jasa, produksi, atau perdagangan. Fokus usaha disarahkan para potensi daerah, prospek usaha dan karakteristik peserta. Keberadaan sektor wisata, kuliner, dan ekonomi kreatif di Kota Makassar merupakan potensi yang besar untuk dimanfaatkan sebagai objek atau lokasi pelatihan tersebut.

Kedua, Balai Diklat Keuangan Makassar perlu memperbanyak frekuensi pelaksanaan open class di luar pelatihan/pembelajaran regular mengingat tingginya kebutuhan kompetensi keuangan negara khususnya dari Pemerintah Daerah. Balai Diklat Keuangan Makassar seharusnya membuka diri terhadap keikutsertaan peserta dari kementerian/lembaga dan Pemerintah Daerah di luar Kementerian Keuangan. Selama ini peserta diklat hanya dari Kementerian Keuangan. Balai Diklat Keuangan Makassar seyogyanya dapat memberikan layanan diklat, bimbingan teknis, workshop, dan sejenisnya kepada satuan kerja yang selama ini tidak tersentuh oleh pelatihan-pelatihan reguler. Dengan begitu, Balai Diklat Keuangan Makassar akan terdorong untuk inovatif dan kreatif dalam merancang dan memberikan layanan diklat. Hal ini relevan dengan nilai kesempurnaan yang dikembangkan di Kementerian Keuangan, yakni selalu berusaha untuk memberikan yang terbaik. Hal ini juga merupakan bentuk kepedulian Balai Diklat Keuangan Makassar terhadap pengelolaan keuangan negara/daerah di semua instansi pemerintah. Di samping itu, sikap inovatif dan kreatif juga sangat mendukung terwujudnya good governance.

\section{KESIMPULAN}

Berdasarkan hasil analisis dan pembahasan dapat disimpulkan bahwa :

1. Balai Diklat Keuangan Makassar dalam hal strategi pengembangan saat ini telah mencoba secara optimal untuk memanfaatkan kekuatan untuk mengurangi kelemahan dimana faktor kekuatan yang dimiliki lebih dominan daripada faktor kelemahannya;

2. Balai Diklat Keuangan Makassar dalam keunggulan kompetitif, juga berada pada posisi relatif baik dalam menghadapi lingkungan eksternalnya dimana Balai Diklat Keuangan Makassar telah mencoba secara optimal untuk memanfaatkan peluang yang ada untuk menghadapi ancaman dari eksternal organisasi;

3. Balai Diklat Keuangan Makassar saat ini berada pada posisi yang kuat dan berpeluang. Rekomendasi strategi yang diberikan dalam keunggulan bersaing adalah progresif, karena organisasi dalam kondisi prima dan mantap sehingga sangat dimungkinkan untuk lebih melakukan ekspansi, memperbesar pertumbuhan dan meraih kemajuan secara maksimal;

4. Strategi-strategi keunggulan bersaing Balai Diklat Keuangan Makassar yang dapat dilakukan saat ini adalah dengan merancang dan melaksanakan program pelatihan dengan memanfaatkan kearifan lokal yang ada di Sulawesi Selatan secara khusus dan Indonesia Timur secara umum, misalnya pada sektor wisata, kuliner, dan ekonomi kreatif dan memperbanyak frekuensi pelaksanaan Open Class di luar pelatihan/pembelajaran regular mengingat tingginya kebutuhan kompetensi keuangan negara khususnya dari Pemerintah Daerah; dan adanya disrupsi teknologi informasi.

\section{DAFTAR PUSTAKA}

Arikunto, S., dan Jabar, C.S.A. (2008). Evaluasi Program Pendidikan. Bumi Aksara. 
Associate, S.A. (2012). Effect of Core Competence on Competitive Advantage and Organizational Performance. International Journal of Business and Management, Vol.7, No.1, pp.192-205.

Biodi, M., \& Sanawiri, B. (2017). Analisis Lingkungan Industri Guna Menentukan Business Strategy dalam Rangka Mencapai Keunggulan Bersaing (Studi pada Pr. Alfi Putra). Jurnal Administrasi Bisnis, 50(3), 172-181.

Ghozali, I. 2006. Aplikasi Analisis Multivariat Dengan Program SPSS-Cetakan Keempat. Badan Penerbit Universitas Diponegoro Semarang

Hartono, J. 2011. Metodologi Penelitian Bisnis: Salah Kaprah dan Pengalaman-pengalaman. BPFE, Yogyakarta.

Hartono, J. 2011. Metodologi Penelitian Bisnis: Salah Kaprah dan Pengalaman-pengalaman. Yogyakarta: BPFE.

Indriyani, E., Harini, C., \& Fathoni, A. (2018). Analisis Swot Sebagai Dasar Penentu Strategi Bersaing Pt. Paragon Technology and Innovation (Wardah Kosmetik). Journal of Management, 4(4).

Laporan Kinerja (LAKIN) Balai Diklat Keuangan Makassar Triwulan III Tahun Anggaran 2019.

Malik, R., \& Said, S. (2019). Integrasi Total Quality Management dan Supply Chain Management Terhadap Keunggulan Bersaing dan Kinerja Perusahaan (Studi Pada PT. Semen Tonasa). Journal of Industrial Engineering Management, 4(1), 55-65.

Manambing, A., Mandey, S., \& Tielung, M. V. (2018). Analisis Pengaruh Orientasi Pasar dan Keunggulan Bersaing Terhadap Kinerja Pemasaran (Studi Kasus Umkm Kuliner Tinutuan di Manado). Jurnal EMBA: Jurnal Riset Ekonomi, Manajemen, Bisnis dan Akuntansi, 6(4).

Marlina, E. (2017). Analisis Pengaruh Activity Based Costing Terhadap Keunggulan Bersaing Perguruan Tinggi. Prosiding CELSCiTech, 2, eco_28-eco_25.

Peraturan Menteri Keuangan Nomor 177/PMK.01/2012 tanggal 6 November 2012 tentang Perubahan Atas Peraturan Menteri Keuangan Nomor 66/PK.01.2009.

Peraturan Menteri Keuangan Nomor 177/PMK.01/2012 tentang Struktur Organisasi Badan Pendidikan dan Pelatihan Keuangan.

Porter, M. (2001). Competitive Strategy. Jakarta : PT. Gramedia.

Rangkuti, F. (2015). Analisis SWOT Teknik Membedah Kasus Bisnis. Jakarta, PT.Gramedia Pustaka Utama.

Rangkuti, F. (2015). Riset Pemasaran. Jakarta, PT. Gramedia.

Rangkuti, F. 2004. Analisis SWOT Teknik Membedah Kasus Bisnis. PT. Gramedia, Jakarta.

Russell, S.N. dan Millar, H.H. (2014). Exploring the Relationships among Sustainable Manufacturing Practices, Business Performance and Competitive Advantage : Perspectives from a Developing Economy. Journal of Management and Sustainability,Vol. 4, No. 3, pp.37-54.

Sekaran, U. (2006). Metode Penelitian Bisnis. Jakarta : Salemba Empat.

Sugiyono, 2005. Metode Penelitian Bisnis. Alfabeta, Bandung.

Sulistyawati, A. I., Indarto, I., \& Saifudin, S. (2018). Beberapa Faktor yang Mempengaruhi Keunggulan Bersaing pada UMKM Handycraft di Semarang. Prosiding Seminar Nasional Unimus (Vol. 1).

Triton, P.B 2005. Riset Statistik Parametrik: SPSS13.00 for windows. Yogyakarta : Andi. 